\title{
A benthic richness hotspot in the Southern Ocean: slope and shelf cryptic benthos of Shag Rocks
}

\author{
DAVID K.A. BARNES \\ British Antarctic Survey, NERC, High Cross, Madingley Road, Cambridge CB3 OET, UK \\ dkab@bas.ac.uk
}

\begin{abstract}
Shelf and slope cryptofauna were sampled at the most northerly shelf environments within the Southern Ocean, Shag Rocks. The area is remarkably rich, with seven phyla, 10 classes, 40 families and 81 species on $0.36 \mathrm{~m}^{2}$ of shelf boulders. A large proportion of genera and species found had not been seen there before, some were new to science and species accumulation curves did not approach an asymptote. Current estimates of benthic diversity are clearly still too low if even well studied locations and depths reveal so much novelty with such little sample effort. Proportions of new species were higher in slope samples showing how little we know of this important depth. Significantly, life was just as rich and, surprisingly, abundant on boulders from continental slope depths. Clearly there are places where the continental slope around Antarctica harbours a wealth of species with potential to resupply the shelf if life was 'bulldozed' off it by past ice shelf expansions during glacial maxima. Some species on boulders from $1500 \mathrm{~m}$ also occur as shallow as the Antarctic intertidal zone. That this rich fauna was 'Antarctic' in character shows the extremes, e.g. sea temperature $\left(>4^{\circ} \mathrm{C}\right.$ in summer), that they can adapt to given long enough time periods.
\end{abstract}

Received 19 July 2007, accepted 23 October 2007

Key words: Antarctica, biogeography, Bryozoa, Polychaeta, Scotia Arc, sub-Antarctic islands

\section{Introduction}

There is growing consensus on levels of near-future warming but little understanding of how some of the most biodiverse areas such as the seabed will respond. Rapid regional warming has made knowledge of life at locations such as Shag Rocks (near South Georgia, Southern Ocean) particularly important for a number of reasons. Firstly, this is where the Antarctic Circumpolar Current (ACC) and its strongest jet, the Polar Front (PF) reach their most northerly range. Biota at nearby South Georgia are subAntarctic on land but many typical Antarctic species occur in the sea (Barnes et al. 2006a). These most northerly benthos of the Southern Ocean live in shallow (top $\sim 40 \mathrm{~m}$ ) sea temperatures of more than $4^{\circ} \mathrm{C}$ in the summer (Holeton et al. 2005) yet at deep slope depths $(1500 \mathrm{~m})$ temperatures rarely exceed $2^{\circ} \mathrm{C}$. Thus the Antarctic endemics amongst this fauna show the temperature extremes that the current fauna can and are living in. This is of particular relevance to predicted rises in regional sea temperatures and whether most Antarctic ectotherms will be able to cope (Peck et al. 2004). Of crucial importance then is how much commonality there is between the slope and shelf faunas and whether the shelf fauna is mainly Antarctic, cool temperate or a mixture. Secondly, Shag Rocks are part of the only semi-continuous link (Scotia Arc) between Antarctica and northerly continental shelf and slope. They represent a likely first point within the Southern Ocean, which temperate species shifting their range southwards would reach. Nearby South Georgia has been the greatest point for arrival and establishment of non-indigenous terrestrial species within the Southern Ocean (Frenot et al. 2005) and was also the location of the first finding of a marine animal non-indigenous to the Southern Ocean (Ralph et al. 1976). Thirdly, locations such as Shag Rocks, South Georgia and the South Orkney Islands are isolated but old and as such provide valuable context to interpreting age as a factor in colonisation and richness, for example of young isolated islands such as Bouvetøya or the South Sandwich Islands (Arntz et al. 2006, Kaiser et al. 2008).

The Southern Ocean shelf environment is thought to be typically rich (Brey et al. 1994, Clarke \& Johnston 2003) with high levels of endemism (Arntz et al. 1997). A handful of algae are the only known established invaders (Clayton et al. 1997, Wienke personal communication 2007). In places, such as around the West Antarctic Peninsula (WAP), Weddell Sea and Ross Sea, the continental shelf has now been quite well sampled. By comparison, the Antarctic deep sea and especially slope depths are poorly known (Piepenburg et al. 2002, Brandt et al. 2007) - yet knowledge of the fauna there is very important. If life has been bulldozed to the shelf edge by ice sheets during successive glacial maxima (see Thatje et al. 2005) it is from the slope refugia that fauna could mainly recolonize. Deep shelf and slope depths are also potentially important refugia for the near future if regional warming of shelf seas (Meredith \& King 2005) follows rapidly rising air temperatures and aerial $\mathrm{CO}_{2}$ patterns (King et al. 2003). 


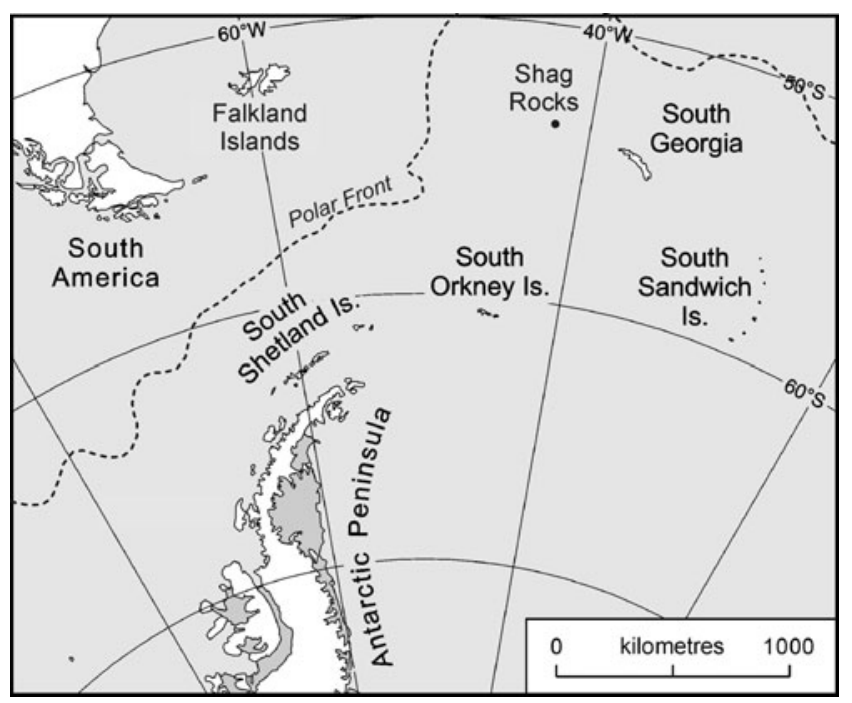

Fig. 1. The position of Shag Rocks relative to South Georgia and other islands in the Scotia arc, Southern Ocean.
The marine fauna around South Georgia and Shag Rocks has been studied by many expeditions since the later 1800s. Most sampling that has been carried out has used corers (Piepenburg et al. 2002), photography (Teixido et al. 2002), Agassiz and other trawls (e.g. Griffiths et al. 2008). Cryptic fauna are likely to be drastically undersampled by all such methods yet may comprise a significant contribution to benthic richness. For example, a recent investigation of Scotia Arc cryptic bryozoans (López de la Cuadra \& Garcia Gómez 2000) found $29 \%$ of shelf species in the Shag Rocks/South Georgia were new to the region or to science. The current study investigates levels of cryptofaunal richness, novelty (new species to the area or science) and commonality of taxa at Antarctic shelf and slope depths. It is hypothesized that the higher richness on the continental shelf compared with the slope is due to undersampling of the latter. That is, that species accumulation curves on the shelf and slope will have similar trajectories with sample size (assuming the habitats on the shelf and slope are otherwise similar). Food is potentially much more abundant in the shallows so it is also hypothesized that shelf abundance will be much higher.

Table I. Total abundance and species richness of Phyla, classes and families on boulder samples from Shag Rocks, Southern Ocean. Areas sampled are $0.36 \mathrm{~m}^{2}$ and $0.24 \mathrm{~m}^{2}$ for shelf and slope respectively.

\begin{tabular}{|c|c|c|c|c|c|c|c|c|c|}
\hline \multirow[t]{2}{*}{ Taxa } & \multicolumn{2}{|c|}{ Shelf - $200 \mathrm{~m}$} & \multicolumn{2}{|c|}{ Slope - $1500 \mathrm{~m}$} & \multirow[t]{2}{*}{ Taxa } & \multicolumn{2}{|c|}{ Shelf - $200 \mathrm{~m}$} & \multicolumn{2}{|c|}{ Slope - $1500 \mathrm{~m}$} \\
\hline & abundance & species & abundance & species & & abundance & species & abundance & species \\
\hline Annelida & & & & & Bryozoa & & & & \\
\hline Polychaeta & & & & & Stenolaemata & & & & \\
\hline Serpulidae & 9 & 1 & 36 & 3 & Cerioporidae & 1 & 1 & & \\
\hline Spirorbidae & 179 & 5 & 59 & 5 & Diaperoeciidae & 2 & 1 & & \\
\hline Brachiopoda & & & & & Filisparsidae & & & 2 & 1 \\
\hline Articulata & & & & & Frondiporidae & 1 & 1 & 2 & 1 \\
\hline Craniidae & & & 3 & 1 & Pustuloporidae & & & 6 & 1 \\
\hline Bryozoa & & & & & Stomatoporidae & 3 & 1 & 1 & 1 \\
\hline Gymnolaemata & & & & & Tubuliporidae & 58 & 5 & 5 & 2 \\
\hline Arachnopusiidae & 28 & 3 & & & Chordata & & & & \\
\hline Aspidostomatidae & 3 & 1 & 2 & 1 & Ascidiacea & & & & \\
\hline Beaniidae & 4 & 1 & & & Didemnidae & 14 & 1 & & \\
\hline Cellariidae & 4 & 1 & & & Thourellidae & 40 & 2 & 43 & 1 \\
\hline Celleporidae & 21 & 6 & 5 & 1 & Hydrozoa & & & & \\
\hline Cribrilinidae & 23 & 1 & & & Staurothecidae & 25 & 3 & 7 & 1 \\
\hline Eminooeciidae & 1 & 1 & & & Stylasteridae & 3 & 1 & 3 & 1 \\
\hline Exochellidae & 52 & 5 & 2 & 1 & Mollusca & & & & \\
\hline Hippopodinidae & 11 & 3 & & & Bivalvia & & & & \\
\hline Hippothoidae & 51 & 2 & & & Phylobryidae & 1 & 1 & & \\
\hline Lacernidae & 22 & 2 & & & Porifera & & & & \\
\hline Microporellidae & 34 & 4 & 16 & 5 & Calcarea & & & & \\
\hline Microporidae & 55 & 1 & 22 & 1 & Unknown & 2 & 1 & & \\
\hline Phidoloporidae & 3 & 1 & & & Demospongiae & & & & \\
\hline Schizoporellidae & & & 1 & 1 & Mycalidae & 7 & 1 & 3 & 1 \\
\hline
\end{tabular}




\section{Method}

\section{Study site}

Shag Rocks, in the Atlantic sector of the Southern Ocean, is an isolated archipelago represented above the sea surface by just a few low lying rocks. The shelf and slope of this region is amongst the northernmost part of the Scotia Arc within the Polar Front (Fig. 1). The Antarctic Circumpolar Current flows through the mountainous shelf and slope in an ENE direction. Sea surface temperatures at the time of sampling (summer - March 2006) were $c .0 .8^{\circ} \mathrm{C}$ but typically range (year round) from just below $-1{ }^{\circ} \mathrm{C}$ to $c .4^{\circ} \mathrm{C}$ (Barnes et al. 2006b). The continental shelf samples were collected at $53.57^{\circ} \mathrm{S}, 40.91^{\circ} \mathrm{W}$ and the continental slope samples were nearby at $53.63^{\circ} \mathrm{S}, 40.90^{\circ} \mathrm{W}$.

\section{Sample and analysis protocol}

Benthic samples were taken on the BIOPEARL JR144 cruise of the RRS James Clarke Ross between 203-212 m (shelf) and 1496-1576 m (slope) depths. Collections were made on 11 April 2006 by dragging a $2 \mathrm{~m}$ wide Agassiz trawl for 15 and 35 minutes at shelf and slope depths resulting in trawl distances of $408 \mathrm{~m}$ and $859 \mathrm{~m}$. These trawls yielded 50 and 8 boulders (comprising 3639 and $2406 \mathrm{~cm}^{2}$ surface area) from shelf and slope depths respectively. Thus boulders from the shelf were mainly smaller than those on the slope but otherwise similar (e.g. in terms of shape, rugosity and mineralogy). The boulders present were briefly examined for delicate fauna and air-dried prior to examination under binocular microscope. Boulders from

Table II. Previously recorded $(+)$, first time found in area (O), first time found in area and new southern limit (S), first time found in area and new northern limit (N) and new species ' ( )'. Other taxa found in the samples but not listed were only identified to genus level.

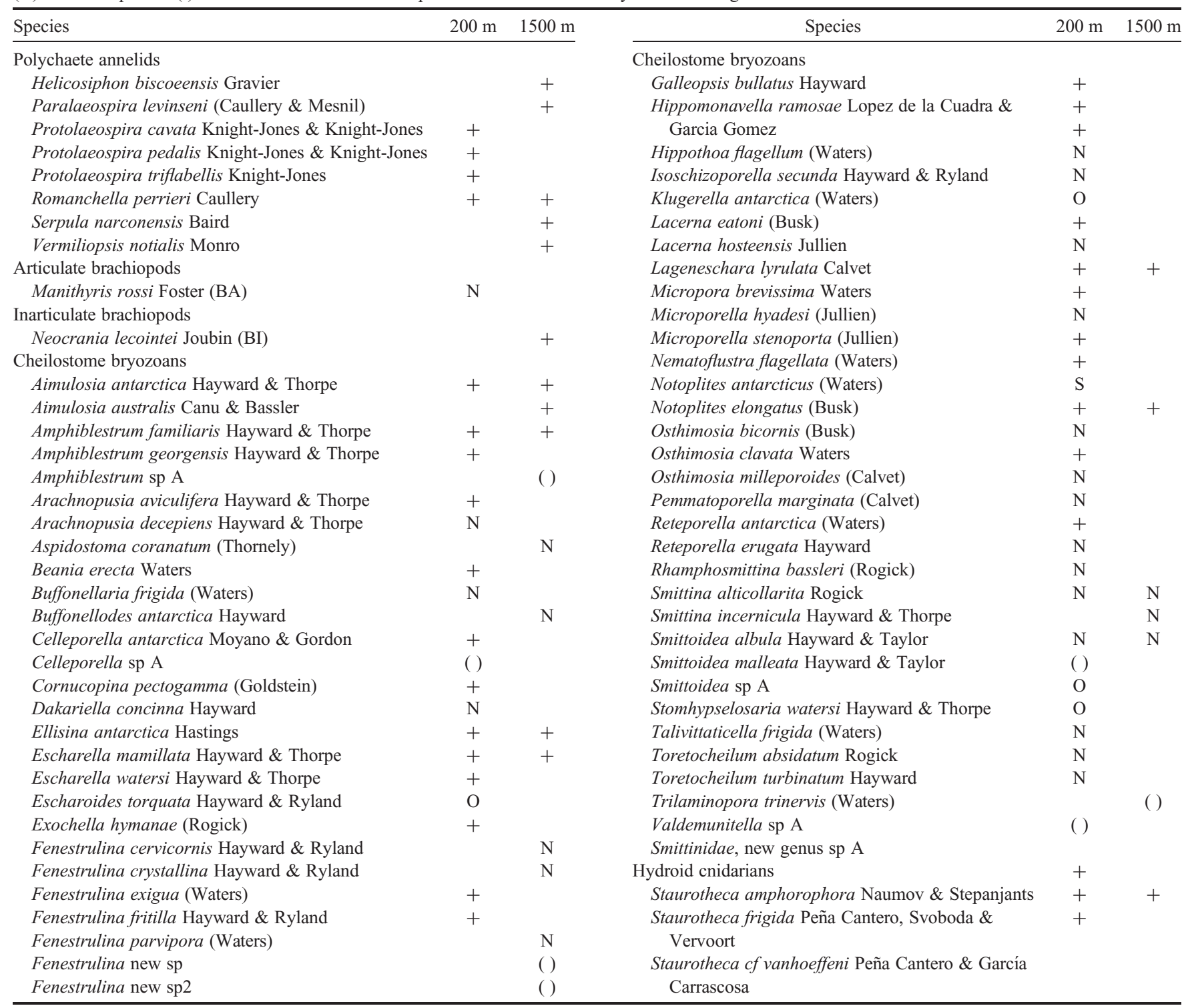


the shelf had 863 recruits on and slope boulders were colonized by 307 recruits. All recruits were identified to the lowest taxonomic level possible using original literature and help from specialist taxonomists. Species accumulation curves were constructed to assess whether an asymptote had been reached and to compare rates of species accumulation at shelf and slope depths. Abundance and density of recruits were plotted again log transformed area and tested for a line of best fit. Where the line of best fit was a significant linear relationship, associated ANOVA was performed. Densities of recruits were compared between shelf and slope samples using one-way ANOVA, having established data normality.

The number and identity of cheilostome bryozoans present in the shelf samples were compared with those previously recorded from Shag Rocks and South Georgia (e.g. Hayward 1995, Lopez de la Cuadra \& Garcia Gomez 2000, author's unpublished database). Richness (number of species) and faunistic similarity between the bryozoans in the region was compared using Bray Curtis index on untransformed data (using the software package Biodiversity Pro). The regions used were as recognized in previous biogeographic studies (see Barnes \& Griffiths 2008) and data were from shelf and slope depths combined and across habitats.

\section{Results}

In just $0.36 \mathrm{~m}^{2}$ and $0.24 \mathrm{~m}^{2}$ area of boulders examined, representatives of seven and five phyla and 10 and seven classes were found alive at the time of capture on shelf and slope samples respectively (Table I). This study shows that at the northernmost edge of the Southern Ocean the continental slope, as well as the shelf, can be extremely rich in cryptofauna across taxonomic levels. Fauna occupied $30.2 \%$ (range $8-67 \%$ ) of space on shelf boulders, significantly more (One way ANOVA, $\mathrm{F}_{1}=14$, $P<0.001)$ than on slope boulders $(4.9 \%$, range $2-11 \%)$. Bryozoans occupied the most space on $94 \%$ of shelf boulders and three out of the eight boulders from the Continental Slope. Polychaetes dominated space on five of the eight slope boulders, in particular the calcareous tubes of serpulids and spirorbids. The Spirorbidae were the most abundant family on both shelf and slope boulders, but cheilostome and cyclostome bryozoan and octocoral families were also highly abundant (Table I). Total abundance increased linearly with (log) boulder surface area but densities significantly decreased (both $r^{2}>30 \%$, ANOVA, $\left.\mathrm{F}_{1}>20, P<0.01\right)$. Standardized for $(\log )$ area, densities of cryptofaunal recruits on shelf boulders were surprisingly not significantly different between shelf and slope boulders (one-way ANOVA, $\mathrm{F}_{1}=2.11, P=0.15$ ).

The shelf and slope trawls caught a wide variety of megaand macrobenthos but boulder dwelling cryptofauna dominated both abundance and the total numbers of
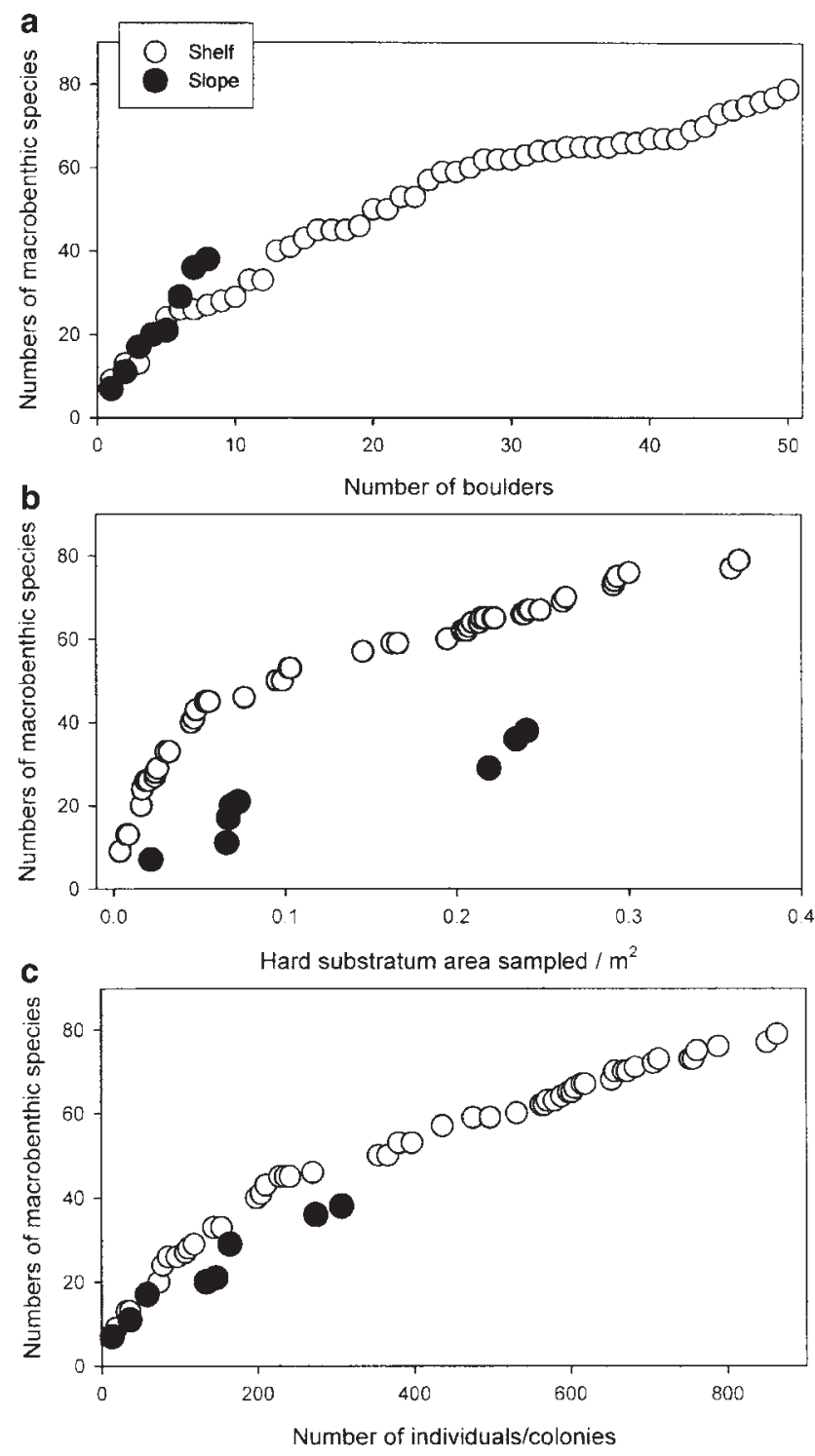

Fig. 2. Species accumulation curves with sample size and area. Total numbers of encrusting species with a. numbers of boulders sampled, b. area of boulders sampled, and c. numbers of individuals/colonies sampled.

families, genera and species in the samples. Some of the phyla (e.g. brachiopods) and classes (e.g. stenolaemate bryozoans) represented on the boulder samples were not otherwise recorded in the trawl samples and the vast majority of the families, genera and species were only found on boulders. Cheilostome bryozoans were highly diverse and the most family, genera and species rich taxon in both shelf and slope samples (Tables I \& II). Eleven genera of cyclostomes were recognized and determined to morphospecies level but even with specialist help these species could not be identified and many may be new. Six of these, Bientalophora, Diaperoecia, Exidmonea, Filifascigera, Nevianipora and Oncousoecia have not been reported from Shag Rocks, the Scotia Arc or anywhere in 


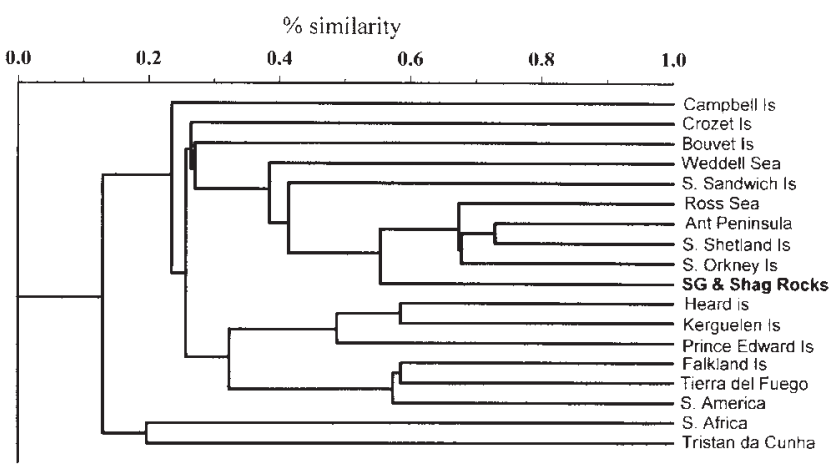

Fig. 3. Bray Curtis similarity dendrogram of cheilostome bryozoan species compositions from continent edges and islands around the Southern Ocean. Data from Barnes \& Griffiths (2008). $\mathrm{SG}=$ South Georgia.

West Antarctica before. All the cheilostomes were also determined to species level, 53 to named species, six to new species of existing genera and a further one to a new species of a new genus (Table II). Thus on the shelf $6 \%$ $(3 / 49)$ of the cheilostomes were new species and on the deeper slope boulders 21\% (4/19) of species were new. Some of the known species were only known from a single specimen or in the case of Dakariella concinna from a single fragment of a colony. A third of shelf and half of the slope cheilostome species, which were not new, constituted new northernmost records for Antarctic endemics. Some had not been previously recorded within thousands of kilometres from Shag Rocks but only Notoplites elongatus is the first Southern Ocean record for a species otherwise known north of the Polar Front. Of all the species identified only $11 \%(8 / 73)$ were found on both shelf and slope boulders. Although percent cover of the shelf boulders was typically six times higher, species density (standardized for [log] area) was not significantly different between shelf and slope boulders (one-way ANOVA, $\mathrm{F}_{1}=0.04, P=0.8$ ). Polychaetes and bryozoan colonies on shelf rocks were just much larger. Species accumulation curves revealed neither shelf nor slope faunas had approached asymptote (Fig. 2). By number of boulders sampled, slope samples showed a steeper species accumulation curve (Fig. 2a) whereas if areas were compared the pattern was the converse (Fig. 2b). Probably the most meaningful method of assessing rates of species accumulation was using individual/colony number, which showed similar rates in the shelf and slope samples (Fig. 2c).

Previously 97 cheilostomes were known from the Shag Rocks/ South Georgia region (data in Barnes \& Griffiths 2008) but this study increases this to a total of 127 cheilostomes. The most similar faunas to those at Shag Rocks/ South Georgia are other localities in the Scotia Arc, the Antarctic Peninsula and the Ross Sea (Fig. 3). Interestingly the South Sandwich Islands, the shelf area closest geographically, have lower levels of similarity. It is clear that faunas of the so-called 'sub-Antarctic' islands, at least in the case of the bryozoans, may have little in common.

\section{Discussion}

Despite the paucity of samples, the current study has made it apparent that shelf and slope boulders in the Shag Rocks area can be very rich across multiple taxonomic levels. Despite not being apparent from polar literature to date, cryptofauna can dominate the benthos, at least locally, at family, genus and species levels. A large proportion of genera (e.g. 6 of 11 cyclostome bryozoans) and species (e.g. 35 of 60 cheilostome bryozoans) found had not been seen in the South Georgia region before, some were new to science and species accumulation curves did not approach asymptote. Current estimates of benthic diversity (Clarke \& Johnston 2003) are clearly still far off if even well studied locations and depths reveal so much novelty with such little sampling effort. Surprisingly, neither richness nor abundance significantly differed between shelf and slope depths, but their faunas and space occupation levels were quite different.

\section{Continental shelf mega- and macrofauna}

The phyla and classes of animal found on the shelf at Shag Rocks were similar to assemblages that have been reported from many Antarctic locations (Arntz et al. 1994, 2005). The fauna was predominantly suspension feeders and their predators. Of the species identified, the polychaetes have a known wide distribution (Knight-Jones \& Knight-Jones 1984) whereas the others were mainly Antarctic species. Shag Rocks and the South Georgia area represent an extreme geographic and sea temperature limit for the Antarctic fauna but despite this the benthos there is very rich. Most of the species (46 of 60 [>76\%]) of cheilostome bryozoans, for example, found on Shag Rocks shelf boulders are at their northernmost limit. Of all cheilostome species ever recorded from the Shag Rocks/ South Georgia region $>66 \%$ are at their northernmost limit (data from the current paper and Barnes \& Griffiths 2008). Short term experimental acclimations have shown extreme temperature sensitivity of some Antarctic benthos (Peck et al. 2004). This has caused great concern for the future of Southern Ocean biodiversity. Sea temperatures have been predicted to rise by $\sim 2^{\circ} \mathrm{C}$, in response to regional warming and over the last few decades have already increased (seasonally) by $1{ }^{\circ} \mathrm{C}$ in the Bellingshausen Sea (Meredith \& King 2005). Yet this study shows that species which occur throughout the Antarctic at 'normal' Southern Ocean temperatures are extremely rich on a shelf, which rises to $>4^{\circ} \mathrm{C}$ in summer (Holeton et al. 2005).

Another important aspect of regional warming is that southern temperate species are likely to alter their range, 
that is migrate southwards. The shelf of Shag Rocks is one of the more likely places for non-indigenous marine species (NIS) to arrive. However only with a good knowledge of the identities of current species present at such locations will the first NIS be detectable. Studies of mega and macrobenthos of the shelf or deeper seabeds often do not consider encrusting fauna as sampling methodology used is inappropriate to record it. Most of the taxa reported in the current study are previously known from reports by specialist taxonomists (e.g. Knight Jones \& Knight Jones 1984, López de la Cuadra \& Garcia Gómez 2000 but see Arntz et al. 2005). Yet this study reports seven phyla, 10 classes and at least 40 families of encrusting benthos from just $0.36 \mathrm{~m}^{2}$ of boulder substrate from a single shelf depth trawl. For the size of area sampled this is amongst the richest shallow boulder faunas reported from a sample at either polar region (Barnes 2000, Kuklinski et al. 2006) or anywhere else in the world (Davidson 2005). The total of 81 species found on these shelf boulders is greater than the total number of mega and macrobenthos otherwise found in the same trawl (BAS unpublished data). The cryptofaunal richness alone compares with the richer total mega and macrobenthic species numbers from other polar shelf trawl samples (Arntz et al. 1994, 2005, Kröncke 1998).

Both Shag Rocks and South Georgia are amongst the better studied Antarctic localities, the continental shelf the most trawled depth and the cheilostome bryozoans one of the better known groups in Antarctica (Hayward 1995). The proportion of taxa being found at Shag Rocks which have not been previously reported could, therefore, be argued as a very conservative measure of how well the fauna is known. The most recent shelf collection reported $29 \%$ of the species (López de la Cuadra \& Garcia Gómez 2000) unseen there before and the current study found a massive $47 \%$ of species new to the area. Although there has been great intensity of study around the Southern Ocean and many scientific cruises over the last few decades, we do not seem to be close to meaningfully estimating levels of Antarctic benthic richness except on very small scales. Recent work at one of the more poorly sampled sites Bouvetøya, shows some interesting parallels and contrasts. In 2003 four benthic samples were taken from shelf $(120-550 \mathrm{~m})$ depths at $54^{\circ} 19^{\prime}-54^{\circ} 28^{\prime} \mathrm{S}$ latitudes north and west of the island (see Arntz et al. 2006 for more details). Like Shag Rocks the majority of recent species found had not been reported there before and the assemblages were Antarctic species (Arntz et al. 2006). In contrast to Shag Rocks very few of these species were new to science and the richness was low, reflecting its youth and greater isolation. Whereas the collection of bryozoans at Bouvetøya enabled a first attempt at assessment of geographic affinities of its fauna, the relation of Shag Rocks/South Georgia to other faunas was near unchanged by the current collection (Fig. 3 compared with Barnes 2006 fig. 3). Knowledge of Antarctic slope faunas is probably similar to the levels for poorly studied shelf areas, such as Bouvetøya.

\section{Continental slope mega- and macrofauna}

As with the shelf fauna, recruits at $1500 \mathrm{~m}$ were nearly all suspension feeders despite being a considerable distance from the zone of primary productivity (top $200 \mathrm{~m}$ ). Of the bryozoans from the continental slope sample, (4/19) $21 \%$ were new species, which is probably a reasonable proxy of relative levels of sampling and knowledge of greater depths. This is unsurprising as whilst the Antarctic shelf is comparatively well sampled, slope and abyssal faunas are still little known (Arntz et al. 1994, 2005). Contrary to current paradigms and previous findings elsewhere (see e.g. Rowe et al. 1991, Dauvin et al. 1994, Kröncke 1998), neither richness nor abundance was lower in the slope than the shelf samples. The number of species recorded from the slope samples in total was lower but obviously sensible comparisons depend on sample size. The problem is there are many ways of calculating sample size. By trawl length and boulder surface area the shelf was richer, by boulder number and recruit number slope richness was similar (Fig. 2). Of these methods it is considered here that comparison by recruit number (i.e. individual/colony) is probably the most meaningful.

There has been debate about the extent to which successive glacial maxima have bulldozed life off the Antarctic shelf (grounded ice shelves expanding during ice ages, see Thatje et al. 2005). Even if fauna had been completely and simultaneously removed from the shelves surrounding Antarctica, which seems unlikely, the current study shows that the continental slope can be very rich in taxa and species with potential for resupply. Although only $12.3 \%$ of shelf and slope species were in common in the current samples, nearly all the slope species found here have been described from the Antarctic shelf by previous studies (e.g. for spirorbid polychaetes see Knight Jones \& Knight Jones 1984, and for cheilostome bryozoans see Hayward 1995). Brey et al. (1996) described the Antarctic benthos as unusually eurybathic but for six species found on slope boulders at $1500 \mathrm{~m}$ to also occur in the Antarctic intertidal zone (see e.g. table I in Waller et al. 2006) is remarkable. For example, less than $1 \%$ of Antarctic gastropods and bivalves (renowned as eurybathic) span this same depth range (data from SOMBASE, see Linse et al. 2006).

The current study is the first to the author's knowledge to report levels of abundance in slope samples matching those on the shelf in the Southern Ocean. This may be due largely to the cryptofaunal covered, boulder 'dropstones'. Boulder habitat is probably not that common in environments below shelf depths so normally space for cryptofaunal colonization may be largely just externa (e.g. skeletons) of other organisms. The lower levels of food 


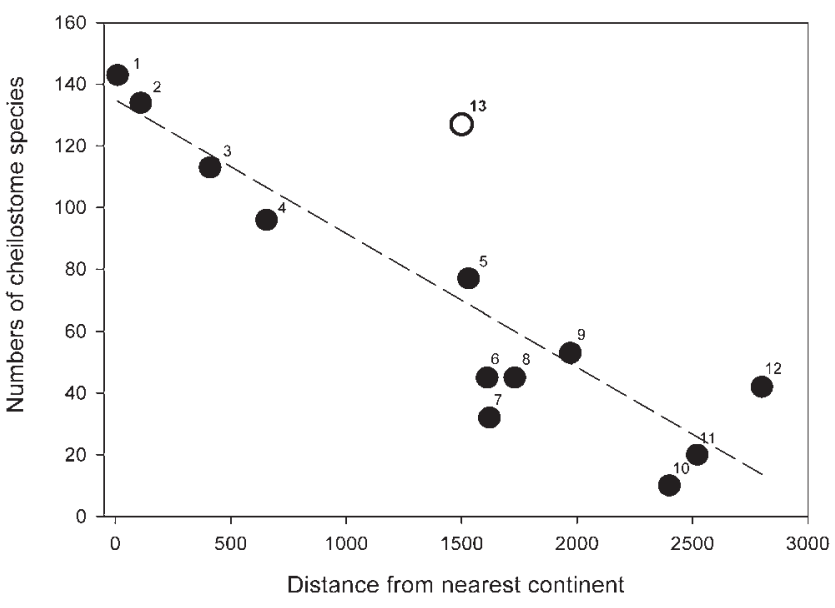

Fig. 4. Cheilostome (bryozoan) species richness of southern temperate to polar continental shelves around some example islands with isolation. Isolation is measured as distance to nearest continent $(\mathrm{km})$. Cheilsotome bryozoan data from Barnes \& Griffiths (2008). The islands are ${ }^{1}$ Tierra del Fuego, ${ }^{2}$ South Shetland, ${ }^{3}$ Falkland/Malvinas, ${ }^{4}$ South Orkney, ${ }^{5}$ Macquarie, ${ }^{6}$ Prince Edward, ${ }^{7}$ Heard, ${ }^{8}$ South Sandwich, ${ }^{9}$ Kerguelen, ${ }^{10}$ Crozet, ${ }^{11}$ Bouvet, ${ }^{12}$ Tristan da Cunha, ${ }^{13}$ South Georgia. The regression line shown is significant (associated ANOVA, $\left.\mathrm{F}_{1}=31.2, P<0.001\right)$ and $r^{2}=74 \%$ ).

availability at slope depths are apparent though by the much lower levels of space occupation (on these boulders), so the average colonist size must be smaller. As most of the slope species in the current study are known from shelf environments elsewhere, slope cryptofauna may not be too distinct from shelf assemblages. Too little is known of slope fauna to judge affinities in the way that can be done for shelf fauna (Fig. 3). Given the concern for the future of Antarctic biodiversity, a strong next step should involve population genetics. Comparisons of individuals of the same species occurring at Shag Rocks shelf and slope depths, or at shelf depths across different Antarctic regions, i.e. living in different temperature regimes, would reveal levels of connectivity and thus physiological flexibility.

High southern latitude bryozoans fit island biogeographic ideas of changing with isolation. The continental shelves of islands close to continent margins are approximately six times more speciose than those more than $2000 \mathrm{~km}$ away (Fig. 4). Richness levels at Shag Rocks/South Georgia are strongly anomalous to the species-isolation relationship. This area is probably a hotspot for a number of reasons primarily because South Georgia is a large and old island which used to be much less isolated than today (Livermore et al. 2007).

\section{Acknowledgements}

Thanks to the crew of the RRS James Clarke Ross and the BIOPEARL team for help with sampling and to Peter
Fretwell for the map of the study region. Special thanks are due for fantastic help with identifications of hydroids, Dr Álvaro Peña Cantero; cyclostome bryozoans, Dr Paul Taylor; cheilostome bryozoans, Dr Peter Hayward; and bivalve mollusc, Dr Katrin Linse. I would also like to thank two anonymous referees for constructive comments leading to an improved manuscript.

\section{References}

Arntz, W.E., Brey, T. \& Gallardo, V.A. 1994. Antarctic zoobenthos. Oceanography and Marine Biology, 32, 241-304.

ARntZ, W.E., GutT, J. \& Klages, M. 1997. Antarctic marine biodiversity: an overview. In Battaglia, B., Valencia, J. \& Walton, D.W.H., eds. Antarctic communities: species, structure and survival. Cambridge: Cambridge University Press, 3-14.

Arntz, W.E., Thatje, S., Gerdes, D., Gili, J.-M., Gutt, J., Jacob, U., Montiel, A., Orejas, C. \& TeiXido, N. 2005. The Antarctic-Magellan connection: macrobenthos ecology on the shelf and upper slope, a progress report. Scientia Marina, 69, 237-269.

Arntz, W.E., Thatje, S., Linse, K., Avila, C., Ballesteros, M., Barnes, D.K.A., Cope, T., Cristobo, F., De Broyer, C., Gutt, J., Isla, E., López-González, P., Montiel, A., Munilla, T., Ramos Esplá, A., Raupach, M., Rauschert, M., Rodriguez, E. \& Teixidó, N. 2006. Missing link in the Southern Ocean: sampling the marine benthic fauna of remote Bouvet Island. Polar Biology, 29, 83-96.

BARNES, D.K.A. 2000. Diversity, recruitment and competition on island shores at polar locations compared with lower latitudes; encrusting community examples. Hydrobiologia, 440, 37-44.

BARNES, D.K.A. 2006. A most isolated benthos: coastal bryozoans of Bouvet Island. Polar Biology, 29, 114-119.

BARNES, D.K.A. \& GRIFFITHS, H.J. 2008. Biodiversity and biogeography of southern temperate and polar bryozoans. Global Ecology and Biogeography, 17, 84-99.

Barnes, D.K.A., Linse, K., Waller, C., Morely, S., Enderlein, P., Fraser, K.P.P. \& Brown, M. 2006a. Shallow benthic faunal communities of South Georgia Island. Polar Biology, 29, 223-228.

Barnes, D.K.A., Fuentes, V., Clarke, A., Schloss, I.R. \& Wallace, M. 2006b. Spatial and temporal variation in shallow seawater temperatures around Antarctica. Deep Sea Research II, 53, 853-865.

Brandt, A., De Broyer, C., De Mesel, I., Ellingsen, K.E., Gooday, A.J., Hilbig, B., Linse, K., Thomson, M.R.A. \& Tyler, P.A. 2007. The biodiversity of the deep Southern Ocean benthos. Philosophical Transactions of the Royal Society of London, B362, 39-66.

Brey, T., Klages, M., Dahm, C., Gorny, M., Gutt, J., Hain, S., Stiller, M., Arntz, W.E., Wägele, J.-W. \& Zimmerman, A. 1994. Antarctic benthic diversity. Nature, 368, 297.

Brey, T., Dahm, C., Gorny, M., Klages, M., Stiller, M. \& Arntz, W.E. 1996. Do Antarctic benthic invertebrates show an extended level of eurybathy? Antarctic Science, 8, 3-6.

Clarke, A. \& Johnston, N. 2003. Antarctic marine benthic diversity. Oceanography and Marine Biology, 41, 47-114.

Clayton, M.N., Wiencke, C. \& Kiöser, H. 1997. New records and subAntarctic marine benthic macroalgae from Antarctica. Polar Biology, 17, $141-149$.

DAVIDSON, I.C. 2005. Structural gradients in an intertidal hard-bottom community: examining vertical, horizontal, and taxonomic clines in zoobenthic biodiversity. Marine Biology, 146, 827-839.

Dauvin, J.C., Kendall, M., Paterson, G., Gentil, F., Jirkov, I., Sheader, M. \& De Lange, M. 1994. An initial assessment of polychaete diversity in the northeastern Atlantic Ocean. Biodiversity Letters, 2, 171-181.

Frenot, Y., Chown, S.L., Whinam, J., Selkirk, P., Convey, P., Skotnicki, M. \& Bergstrom, D. 2005. Biological invasions in the Antarctic: extent, impacts and implications. Biological Reviews, 80, 45-72. 
Griffiths, H.J., Linse, K. \& Barnes, D.K.A. 2008. Distribution of macrobenthic taxa across the Scotia Arc, Southern Ocean. Antarctic Science, 20, 213-226.

Hayward, P.J. 1995. Antarctic Cheilostomatous Bryozoa. Oxford: Oxford University Press, 355 pp.

Holeton, C.L., Nedelec, F., Sanders, R., Brown, L., Moore, C.M., Stevens, D.P., Heywood, K.J., Statham, P.J. \& Lucas, C.H. 2005. Physiological state of phytoplankton communities in the Southwest Atlantic sector of the Southern Ocean, as measured by fast repetition rate fluorometry. Polar Biology, 29, 44-52.

Kaiser, S., Barnes, D.K.A., Linse, K. \& Brandt, A. 2008. Epibenthic macrofauna associated with the shelf and slope of a young and isolated Southern Ocean island. Antarctic Science, 20, 281-290.

King, J.C., Turner, J., Marshall, G.J., Conolley, W.M. \& Lachlan-Cope, T.A. 2003. Antarctic Peninsula climate variability and its causes as revealed by analysis of instrumental records. Antarctic Research Series, 79, $17-30$

Knight-Jones, P. \& Knight-Jones, E.W. 1984. Systematics, ecology and distribution of southern hemisphere spirorbids (Polychaeta; Spirorbidae). In Hutchings, P.A., ed. Proceedings of the First International Polychaete Conference, Sydney, Australia, July 1983. Sydney: The Linnean Society of New South Wales, 197-210.

KRÖNCKE, I. 1998. Macrofauna communities in the Amundsen Basin, at the Morris Jesup Rise and at the Yermak Plateau (Eurasian Arctic Ocean). Polar Biology, 19, 383-392.

KuKLINSKI, P., BARNES, D.K.A. \& TAYLOR, P.D. 2006. Latitudinal patterns of diversity and abundance in North Atlantic intertidal boulder-fields. Marine Biology, 149, 1577-1583.

Linse, K., Griffiths, H.J., Barnes, D.K.A. \& Clarke, A. 2006. Biodiversity and biogeography of Antarctic and sub-Antarctic mollusca. Deep-Sea Research II, 53, 985-1008.
Livermore, R., Hillenbrand, C.-D., Meredith, M. \& Eagles, G. 2007. Drake Passage and Cenozoic climate: an open and shut case? Geochemistry, Geophysics, Geosystems, 8, 101029/2005GC001224

López de la Cuadra, C.M. \& Garcia Gómez, J.C. 2000. The Cheilostomate Bryozoa (Bryozoa: Cheilostomatida) collected by the Spanish 'antartida 8611' expedition to the Scotia Arc and South Shetland Islands. Journal of Natural History, 34, 755-772.

Meredith, M.P. \& King, J.C. 2005. Rapid climate change in the ocean west of the Antarctic Peninsula during the second half of the 20th century. Geophysical Research Letters, 32, 10.1029/2005GL024042

Peck, L.S., Webb, K. \& Bailey, D. 2004. Extreme sensitivity of biological function to temperature in Antarctic marine species. Functional Ecology, 18, 625-630.

Piepenburg, D., Schmid, M.K. \& Gerdes, D. 2002. The benthos off King George Island (South Shetland Islands, Antarctica): further evidence for a lack of a latitudinal biomass cline in the Southern Ocean. Polar Biology, 25, 146-158.

Ralph, R., Maxwell, J.G.H., Everson, I. \& Hall, J. 1976. A record of Mytilus edulis L. from South Georgia. British Antarctic Survey Bulletin, No. 44, 101-102.

Rowe, G., Sibuet, M., Deming, J., Khripouno, A. Tietjen, N.J., Macko, S. \& Theroux, R. 1991. Total sediment biomass and preliminary estimates of organic carbon residence time in deep-sea benthos. Marine Ecology Progress Series, 79, 99-114.

Teixido, N., Garrabou, J. \& Arntz, W.E. 2002. Spatial pattern quantification of Antarctic benthic communities using landscape indices. Marine Ecology Progress Series, 242, 1-14.

Thatje, S., Hillenbrand, C.-D. \& Larter, R.D. 2005. On the origin of Antarctic marine benthic community structure. Trends in Ecology and Evolution, 20, 534-540.

Waller, C., Barnes, D.K.A. \& Convey, P. 2006. Ecological contrasts across an Antarctic land-sea interface. Austral Ecology, 31, 656-666. 